\title{
The radioimmunoassay of triiodothyronine and its clinical application
}

\author{
C. J. EASTMAN ${ }^{1}$, J. M. CORCORAN, R. P. EKINS, E. S. WILliAMS, AND \\ J. D. N. NABARRO
}

From the Institute of Nuclear Medicine, the Middlesex Hospital Medical School, London

Since the identification of triiodothyronine $\left(\mathrm{T}_{3}\right)$ in blood and thyroid tissue by Gross and Pitt Rivers in 1952, relatively little information had accrued until the latter part of the past decade concerning the role of this hormone in normal physiology and that of the thyroid gland. The major difficulty in obtaining this knowledge was the lack of simple, reliable and specific methods for quantitation of $T_{3}$ in blood and other biological fluids. The development of gas chromatographic (Nauman, Nauman, and Werner, 1967) and saturation analysis techniques (Sterling, Bellabarba, Newman, and Brenner, 1969) for the measurement of $T_{3}$ in serum provided a new impetus in this area. In $1968 \mathrm{Hol}-$ lander established the existence of a clinical state of hyperthyroidism in which an increase of $\mathrm{T}_{3}$ appeared to be the major pathogenic factor. This finding has subsequently been confirmed by other workers (Sterling, Refetoff, and Selenkow, 1970; Wahner and Gorman, 1971). It is now well established that as much as $50 \%$ of the $\mathrm{T}_{4}$ secreted by the thyroid may be converted to $T_{3}$ by peripheral deiodination (Brauerman, Ingbar, and Sterling, 1970). It is even possible that $T_{3}$ is the sole biologically active thyroid hormone, as conversion of $\mathrm{T}_{4}$ to $\mathrm{T}_{3}$ in vivo may be an obligatory step in the metabolic action of $T_{4}$ at cellular level, $\mathbf{T}_{4}$ being thus relegated to the role of an inactive prohormone.

Although the saturation analysis technique introduced by Sterling has proved useful, it has not been widely adopted for clinical diagnostic use as it is complex, tedious to perform, and requires large volumes of blood for assay. More importantly, this method is subject to artefactual errors which produce inconstant overestimates of serum $T_{3}$ concentration (Fisher and Dussault, 1971; Larsen, 1971a). A significant advance in $T_{3}$ assay methodology was the production of specific $\mathrm{T}_{3}$ antibodies by Brown, Ekins, Ellis, and Reith (1970) and subsequently the development of a sensitive and

${ }^{1}$ Correspondence to Dr C. J. Eastman, Garvan Institute of Medical Research, St Vincent's Hospital, Sydney, 2010 Australia precise radioimmunoassay for $T_{3}$ in serum extracts (Brown, Ekins, Ellis, and Williams).

\section{Principles and Problems of $\mathbf{T}_{3}$ Radioimmunoassay in Whole Serum}

Early attempts to measure $T_{3}$ in whole serum by radioimmunoassay were unsuccessful due largely to interference by endogenous thyroxine-binding globulin (TBG). Theoretically, it is possible to measure $T_{3}$ by radioimmunoassay in the presence of TBG, if the avidity of the antiserum for $T_{3}$ greatly exceeds that of TBG. In practice, however, this has proved very difficult. A novel approach to overcoming the problem of TBG interference has been the use of chemical compounds structurally similar to $T_{3}$, which competitively inhibit binding of $T_{3}$ to TBG. Compounds which have been employed successfully in this role are listed in table I. Thy-

\begin{tabular}{ll}
\hline Compound & Authors \\
\hline $\begin{array}{l}\text { Thyroxine } \\
\text { Tetrachlorthyronine }\end{array}$ & $\begin{array}{l}\text { Chopra et al (1971) } \\
\text { Salicylate } \\
\text { Merthiolate } \\
\begin{array}{l}\text { Diphenyl hydantoin } \\
\text { Diazepam }\end{array}\end{array}$ \\
$\begin{array}{l}\text { 8-Anilino-1-naphthalene } \\
\text { sulphonic acid }\end{array}$ & Hesch et al (1972) \\
& Chopra (1972); Mitsuma et al \\
& (1972); Chopra et al (1972); \\
\hline
\end{tabular}

Table I Inhibitors of $T_{3}-T B G$ binding useful in $T_{3}$ radioimmunoassay

roxine was first employed by Chopra, Solomon, and Beall (1971) to saturate the binding sites of TBG present in the test serum, thus displacing $T_{3}$ bound to TBG; then serum $T_{3}$, in addition to that added as tracer and as standard, is free to react with the specific $T_{3}$ antibody. Although effective, $T_{4}$ has not been widely used as an inhibitor because of the variable contamination of most $\mathrm{T}_{4}$ preparations with $T_{3}$, the possibility of spontaneous deiodination of $T_{4}$ to $T_{3}$ in the incubation medium, and the 


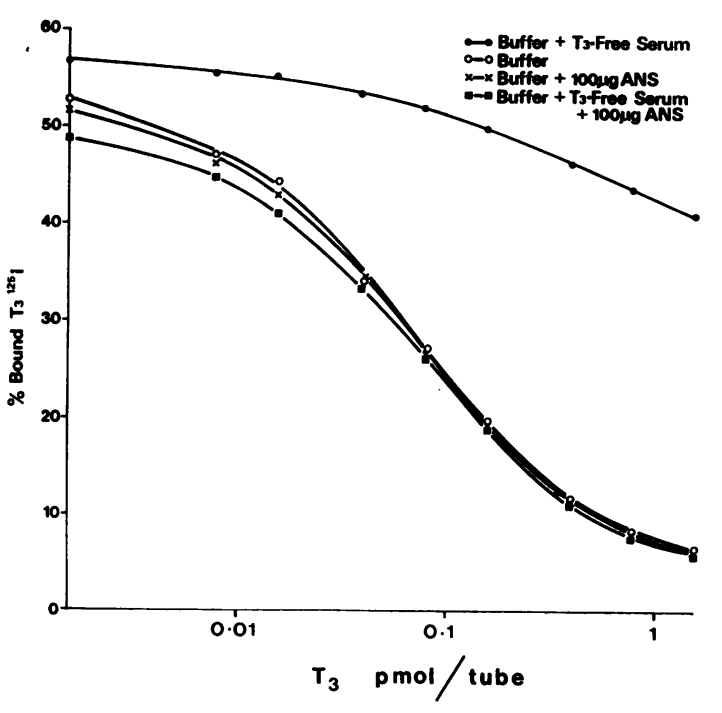

Fig 1 Standard curve for $T_{3}$ using a large selection of antisera.

intrinsic cross reaction of $T_{4}$ with many $T_{3}$ antisera. Tetrachlorthyronine (TCT) is a potent competitive inhibitor of TBG and has been employed successfully in the radioimmunoassay of $\mathrm{T}_{3}$ (Mitsuma, Gershengorn, Colucci, and Hollander, 1971); however, we have found that commercial preparations of TCT crossreact with every antiserum we have tested. It is possible that this cross reaction is due mainly to contamination with trichlorthyronine. Diphenylhydantoin will effectively inhibit $T_{3}$ binding to TBG (Lieblich and Utiger, 1972), but considerable practical problems have been encountered with its use due to the insolubility of this compound in aqueous solutions except under very alkaline conditions. Similar problems have been found using diazepam and other inhibitors which are relatively insoluble in aqueous solutions. Salicylate (Larsen, 1972) and merthiolate (Hesch, Hüfner, and Von Zu Mühlen Mühlen, 1972) have also been used; these compounds show minimal or no cross reaction with most $T_{3}$ antisera and have the added advantage of inhibiting $\mathrm{T}_{3}$ binding to thyroxine-binding prealbumin (TBPA) (Larsen, 1971b). Of the compounds we have tested so far $^{1}$, 8-anilino-1-naphthalene sulphonic acid (ANS) (Chopra, 1972; Mitsuma, Colucci, Shenkman, and Hollander, 1972; Chopra, Ho, and Lam; Eastman, Corcoran, Jequier, Ekins, and Williams, 1973) is the most potent inhibitor of $T_{3}$ and $T_{4}$ binding to $T B G$, showing no significant cross reaction with and causing no alter-

${ }^{1}$ Recently Sterling and Milch (J. clin. Endocr. Metab., 1974, 38, 866) have described inactivation of binding proteins by heat. ED. ation in the equilibrium constants of a large selection of $T_{3}$ antisera $^{2}$ (figure 1 ).

\section{Methods}

ANTISERA

The $T_{3}$ antisera currently in use in our laboratorfo were raised in sheep against small doses of $T_{3}^{\infty}$ conjugate to bovine serum albumin distributed $b$ over multiple intracutaneous sites. Antisera har $\vec{\overrightarrow{ }}$ vested 10 weeks after primary immunization were్ usable in titres of $1 / 30000$ to $1 / 150000$. Cross reactiotr with highly purified $\mathrm{T}_{4}$ was less than $0 \cdot 1 \%$.

DETAILS OF RADIOIMMUNOASSAY METHOD The radioimmunoassay method is outlined in table II. It is essential to use serum free from $\mathrm{T}_{3}$ and

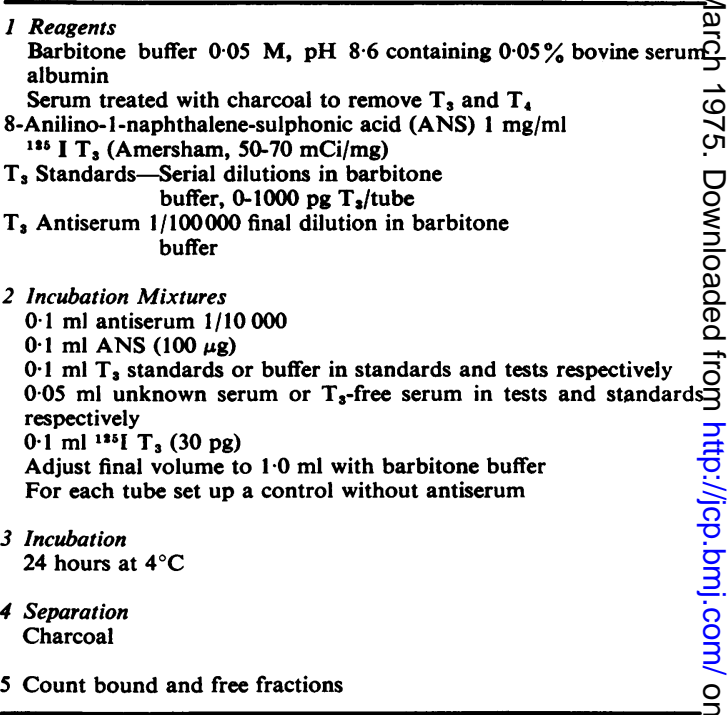

Table II Protocol for $T_{3}$ radioimmunoassay

$T_{4}$ in the standards to make the protein content, $\mathrm{O}$ especially TBG and TBPA, similar to that of the $N$ unknown sera. Thyroid hormone-free serum is readily prepared by repeated treatment of pooled 0 serum with charcoal, using added ${ }^{125} \mathrm{I} \mathrm{T}_{4}$ to monitor

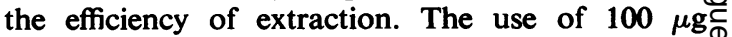
ANS per $50 \mu \mathrm{l}$ of serum represents a two to four- $\stackrel{0}{\longrightarrow}$ fold excess of the mass of inhibitor required to 0 inhibit $T_{3}$ binding to TBG in most serum samples. 0 All reagents are diluted in $0.05 \mathrm{M}$ barbital buffer ${ }_{\odot}$ pH 8.6 to inhibit $T_{3}$ binding to TBPA. With most席

${ }^{2}$ Malkus and Donabedian (Clin. chim. Acta, 1974, 51, 191) report interference by ANS with $\mathbf{T}_{\mathbf{3}}$-binding by two antisera. ED. 


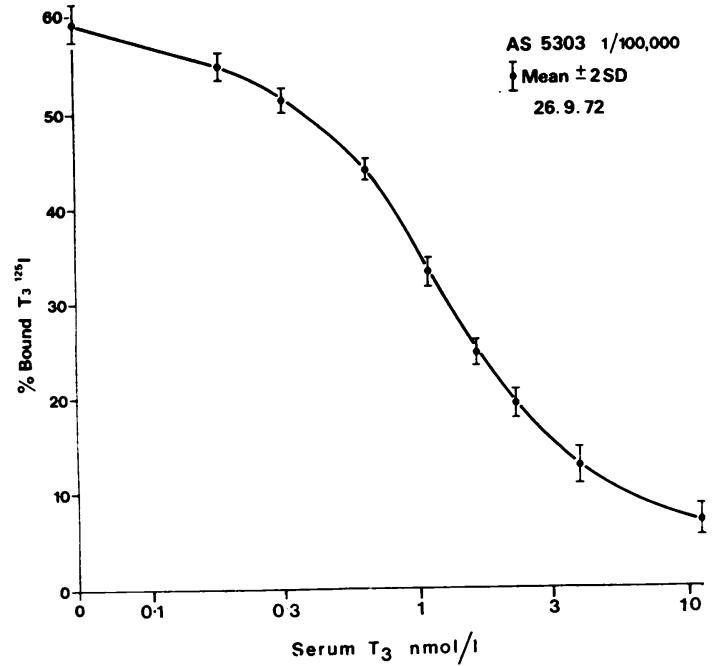

Fig $2 T_{3}$ standard curve.

antisera we have tested, incubation time can be shortened at higher temperatures as equilibrium is attained within one to two hours at $37^{\circ} \mathrm{C}$. Charcoal separation of bound from free hormone, as previously described for $\mathrm{T}_{4}$ (Ekins, Williams, and Ellis, 1969), is simple, quick, and inexpensive, and thus offers several advantages over double antibody separation systems.

A typical standard curve for $T_{3}$ is shown in figure 2. Using the programme of Ekins et al (1969) the assay has been optimized around the mean normal value of about $1.85 \mathrm{nmol} / \mathrm{l}(120 \mathrm{ng} / 100 \mathrm{ml})$ so that the standard curve permits measurement of serum $T_{3}$ concentrations from $0 \cdot 15-6 \cdot 0 \mathrm{nmol} / 1$ (10 to $400 \mathrm{ng} / 100 \mathrm{ml}$ ). Greater sensitivity can be achieved if required. Non-specific binding, ie, the percentage bound ${ }^{125} \mathrm{I} \mathrm{T}_{3}$ in the absence of antiserum, is approximately $10 \%$ and does not vary with $T_{3}$ concentration. It is implied that ANS produces total inhibition of $T_{3}$ binding to endogenous TBG; theoretically this may not be true, but in practice the residual proportion of $T_{3}$ bound to TBG is minute and is within the error of replicate determinations on the same serum sample. Ideally each serum sample should be run without antiserum to act as its own control and thus exclude any error due to residual binding of $T_{3}$ to TBG. Within-batch precision calculated from replicates for a representative assay, expressed as the mean serum $T_{3}$ concentration $\pm 2 \mathrm{SD}$, is $0.59 \pm 0.042$, $1.52 \pm 0.092,3.21 \pm 0.25$, and $12.7 \pm 2.2 \mathrm{nmol} / 1$ $138 \pm 2 \cdot 7,99 \cdot 0 \pm 6 \cdot 0,208 \pm 16 \cdot 0$ and $830 \pm 140$ $\mathrm{ng} / 100 \mathrm{ml}$ ). The between-batch precision expressed as mean serum $T_{3}$ concentration $\pm 2 \mathrm{SD}$ for three quality control sera run in 11 assays was $1 \cdot 36 \pm 1 \cdot 4$,
$2 \cdot 74 \pm 0.27$, and $5.80 \pm 0.46 \mathrm{nmol} / \mathrm{l}(88.5 \pm 8.9$, $177 \cdot 5 \pm 17 \cdot 7$ and $376 \pm 30 \mathrm{ng} / 100 \mathrm{ml})$.

Results and Discussion of Physiological and Clinical Studies

EUTHYROID SUBJECTS

Serum total $T_{3}$ ranged from 1.46 to $2.46 \mathrm{nmol} / \mathrm{l}$ $(95$ to $160 \mathrm{ng} / 100 \mathrm{ml})$ with a mean of $1 \cdot 85, \mathrm{SD} \pm$ $0.27 \mathrm{nmol} / 1$ in 38 healthy euthyroid adults (figure 3). There was no signficant difference between males (mean serum $\mathrm{T}_{3} 1.83 \pm 0.26 \mathrm{nmol} / \mathrm{l}$ ) and females (mean serum $\left.\mathrm{T}_{3} 1.82 \pm 0.29 \mathrm{nmol} / \mathrm{l}\right)$. Females who were pregnant or taking oral contraceptives displayed higher serum $T_{3}$ levels which parallel the changes in serum $T_{4}$ in this group, presumably due to increased circulating TBG levels (figure 3). Twenty-two euthyroid inpatients with no evidence of thyroid disease exhibited serum $T_{3}$ levels within the normal range. The results of serum $T_{3}$ determinations in our normal subjects are comparable with those reported by other workers (Brown et al, 1971; Mitsuma et al, 1971; Lieblich and Utiger, 1972; Larsen, 1972; Hesch et al, 1972), but are considerably lower than the levels measured by saturation analysis (Sterling et al, 1969; Wahner and Gorman, 1971) and by the radioimmunoassay method of Gharib, Ryan, Mayberry, and Hockert (1971) which does not employ TBG inhibitors to measure $T_{3}$ in whole serum. Subnormal $T_{3}$ levels not associated with any evidence of hypothyroidism have been found in patients with low TBG levels, in some patients with anorexia nervosa, and in the immediate newborn period (figure 3 ). It is intriguing that serum $T_{3}$ levels found in cord blood, in the presence of normal serum $\mathrm{T}_{4}$ levels, modestly elevated levels of thyrotrophin (TSH) and elevated TBG levels, should be similar to the serum $T_{3}$ levels we have observed in patients with overt hypothyroidism (figure 4). The explanation for this phenomenon is unknown; however, it does emphasize the dissociation between maternal and fetal thyroid hormone secretion and also suggests that measurement of serum $\mathrm{T}_{3}$ in cord blood cannot be used as a screening test for hypothyroidism in the newborn (Eastman et al, 1973).

\section{PATIENTS WITH THYROID DISEASE}

\section{Hypothyroidism}

In 32 clinically hypothyroid patients, in whom the diagnosis was confirmed by elevated serum TSH and/or the TSH response to thyrotrophin-releasing hormone (TRH), the mean serum $\mathrm{T}_{3}$ concentration was $0.585 \mathrm{SD} \pm 0.38 \mathrm{nmol} / 1(38.1 \pm 24.6 \mathrm{ng} / 100 \mathrm{ml})$. The serum $T_{3}$ level was below the lower limit of 


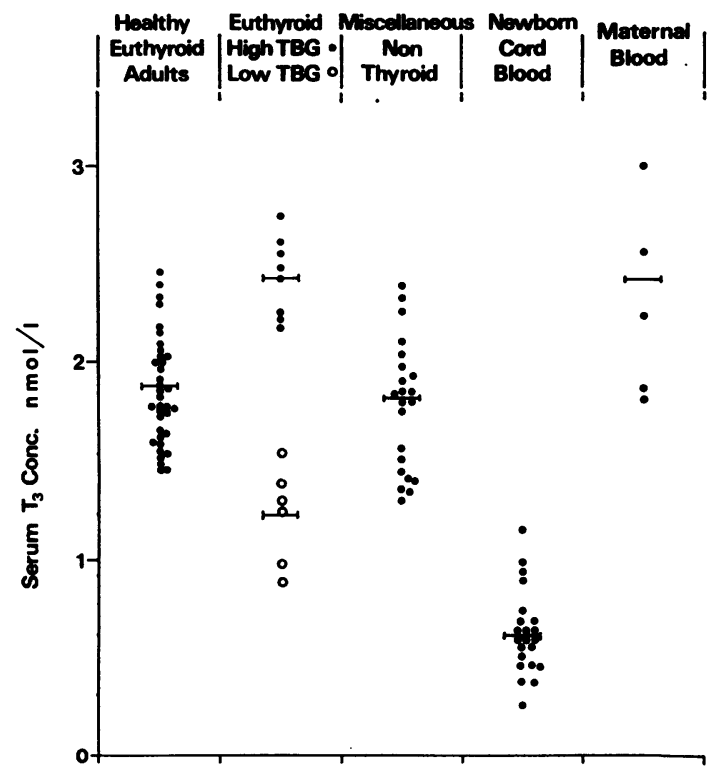

Fig 3 Serum $T_{3}$ levels in healthy euthyroid adults

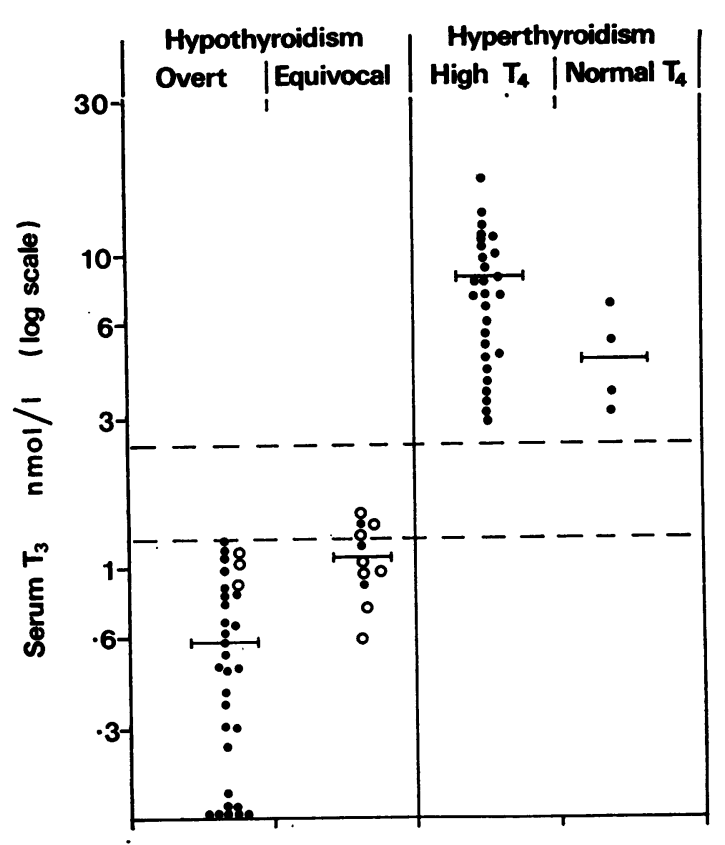

Fig 4 Serum $T_{8}$ levels in cases of hypothyroidism , and hyperthyroidism. the normal range in each patient (figure 4). In general there was a good correlation between the serum $T_{3}$ level and the severity of the hypothyo roidism. Serum $T_{3}$ concentration paralleled serum $T_{5}$ concentration with the exception of three patientswho exhibited subnormal $\mathrm{T}_{3}$ levels but norma出 serum $\mathrm{T}_{4}$ levels. Contrary to some other reports w\& have not encountered any patients with unequivoca\% clinical hypothyroidism in whom the serum $T_{\oplus}$ level is within the normal range. Eleven patients were classified as equivocally hypothyroid of clinical grounds. Serum $T_{3}$ levels were below the normal range in seven of these patients and withis the lower part of the normal range in the other foupo (figure 4). Serum $T_{4}$ levels were within the normait range in eight of the 11 patients.

Acute falls in serum $T_{3}$ levels may occur in some patients in the absence of any clinical signs of hypo? thyroidism, eg, during the course of antithyroid drug therapy for thyrotoxicosis, or during the early postoperative period following pituitary or thyrois surgery. Subnormal $\mathrm{T}_{3}$ values in these circumstances may represent transient changes in thyroid hormone output or may herald the onset of clinical hypothy=roidism. Serial measurements of serum $T_{3}$ concen 0 trations are helpful in assessing the efficacy of antis thyroid drug therapy or the completeness of surgeryo

\section{Hyperthyroidism}

In 28 untreated patients with well defined hyper $\vec{\sigma}$ thyroidism confirmed by an elevated serum $T \bar{\phi}$ and a raised free thyroxine index the serum $T_{3}^{\text {? }}$ concentration ranged from 3.04 to $169 \mathrm{nmol} / \mathrm{P}$. (198 to $1100 \mathrm{ng} / 100 \mathrm{ml}$ ) (figure 4). Four patients with clinical evidence of hyperthyroidism, but with normas serum total $T_{4}$ and free $T_{4}$ levels had serum $T^{9}$ levels ranging from 3.1 to $6.9 \mathrm{nmol} / 1$ (200 to $450 \mathrm{ng} / 100 \mathrm{ml}$ ) and a diagnosis of $\mathrm{T}_{3}$-toxicosis was made in each of these patients according to the criteria of Hollander and Shenkman (1972). Two of the four patients had recurrent thyrotoxicosis having been already treated with antithyroid drugs for conventional thyrotoxicosis with elevated serum $T_{4}$ levels. This finding suggests that $T_{3}$-toxicosis may simply be a variant of conventional thyrotoxi슨 cosis but may be commoner in patients who have undergone previous treatment for thyrotoxicosis? The incidence of $T_{3}$-toxicosis in untreated hyper? thyroid patients in this community is unknown an further experience is required before any definitive estimate can be arrived at.

Miscellaneous thyroid disorders

Serum $T_{3}$ levels were within the normal range in $\mathbb{\mathbb { D }}$ small series of clinically euthyroid patients witk multinodular goitre, untreated endocrine exopho 


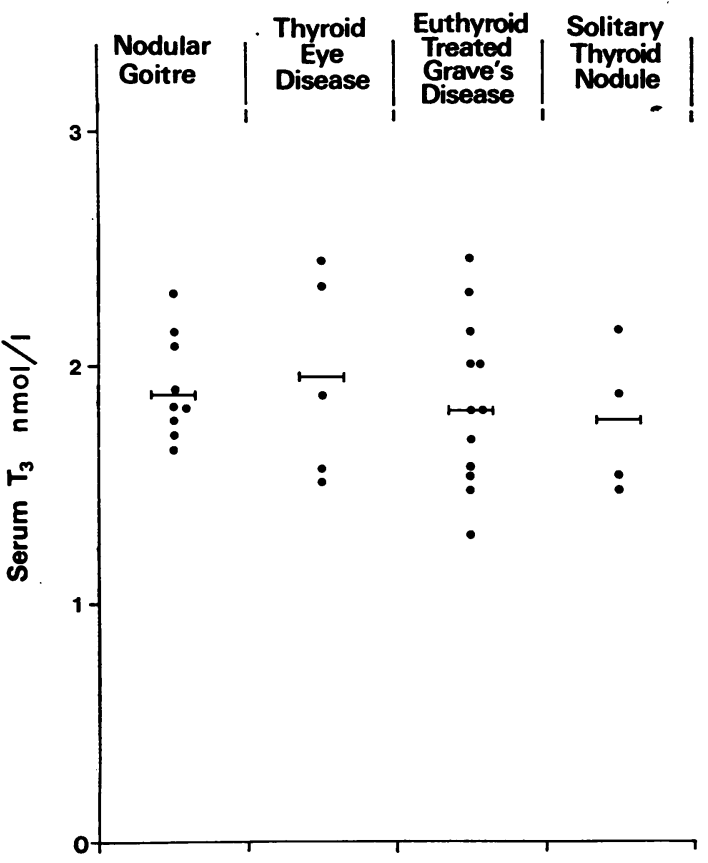

Fig-5 Serum $T_{3}$ levels in a series of clinically euthyroid patients with various thyroid disorders.

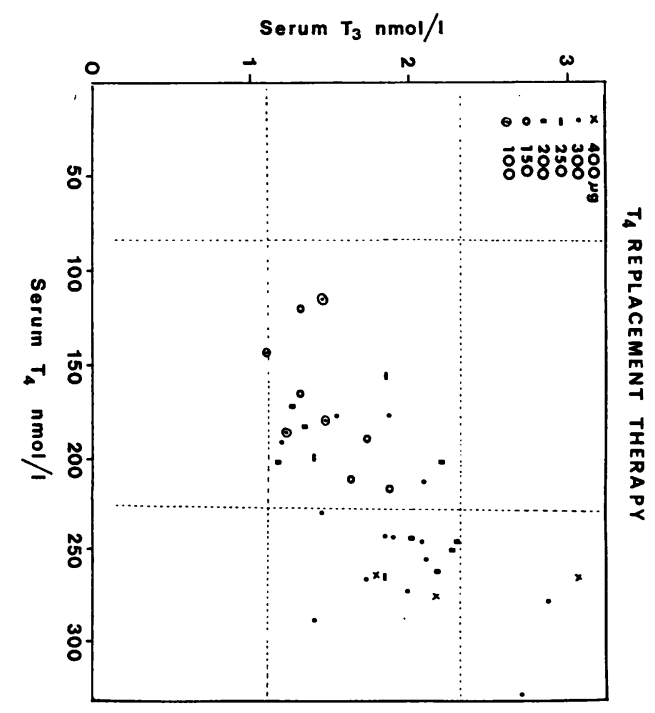

Fig 6 Serum $T_{3}$ and $T_{4}$ levels in 37 patients receiving L-thryoxine replacement therapy. thalmos, treated Graves' disease, and solitary nodules proven by thyroid scintiscans (figure 5).

\section{SERUM T 3 IN PATIENTS ON THYROXINE} REPLACEMENT THERAPY

In patients on thyroxine replacement therapy serum $\mathrm{T}_{\mathbf{4}}$ estimations are not very helpful in assessing the optimal dose of $T_{4}$ for an individual patient. The daily production rate of $T_{4}$ in healthy euthyroid adults is in the vicinity of 80 to $100 \mu \mathrm{g}$ per day (Nicoloff, Low, Dussault, and Fisher, 1972) yet most hypothyroid patients require oral doses of $\mathbf{T}_{4}$ in excess of this amount to maintain a state of euthyroidism. Serum $\mathbf{T}_{4}$ levels in these patients are commonly within the upper part of the normal range or modestly elevated.

Serum $T_{3}$ and $T_{4}$ concentrations were measured in 37 patients on L-thyroxine replacement therapy. Each patient was clinically euthyroid and had been on a stable dose of L-thyroxine for at least one month before investigation. The $T_{4}$ replacement dose varied from $100 \mu \mathrm{g}$ to $400 \mu \mathrm{g}$ per day. Serum $T_{3}$ and $T_{4}$ levels are shown in figure 6 . Serum $T_{4}$ levels were raised in 18 out of 37 patients. The elevated $\mathrm{T}_{4}$ levels were observed predominantly in patients taking $200 \mu \mathrm{g}$ or more of thyroxine per day. By contrast, serum $T_{3}$ levels were elevated above the normal range in only three patients. Increases in serum $T_{3}$ were modest and less than the increases found in the patients with thyrotoxicosis. It is apparent that serum $T_{3}$, presumably derived from peripheral monodeiodination of $T_{4}$, more accurately reflects the metabolic status of the individual patient than does serum $\mathrm{T}_{4}$. Although the factors responsible for this control system are poorly understood, the consistency of the $T_{4} / T_{3}$ ratios in the $T_{4}$-treated patients (mean ratio $83 / 1$ ), at a higher level than those in the untreated euthyroid group (mean 70/1), suggests that conversion of $T_{4}$ to $T_{3}$ is dependent upon available $T_{4}$. Because the treated hypothyroid patients lack $T_{3}$ secreted directly from the thyroid, be it a partial or total lack depending upon the severity of the hypothyroidism, then it is reasonable to assume that more exogenous $T_{4}$ is required by these patients to maintain normal $T_{3}$ levels than is secreted by euthyroid subjects. This could explain the common finding of elevated serum $T_{4}$ levels ${ }^{1}$ and higher $T_{4} / T_{3}$ ratios in the thyroxine-treated patients. The great variability in serum $T_{4}$ levels between patients taking the same dose of $T_{4}$ probably reflects individual variation in intestinal absorption

'Physicians who treat hypothyroidism with just enough thyroxine to suppress the raised TSH level have recently reported that this produces normal serum $T_{4}$ (and $T_{3}$ ) levels, and that the patients become clinically euthyroid-see Evered et al, Brit. med. J., 1973, 3, 131, and Stock et al, New England J. Med., 1974, 290, 529. ED. 
of orally administered $T_{4}$. Further studies are in progress to assess $T_{4}$ absorption and $T_{4}$ to $T_{3}$ conversion in treated hypothyroid patients.

\section{Clinical Utility of Serum $\mathbf{T}_{3}$ Determinations}

At the present time the serum $\mathrm{T}_{4}$ concentration, interpreted in conjunction with an estimate of the degree of saturation of serum thyroid hormonebinding proteins, is generally considered to be the most specific index of thyroid function currently available. The application of radioimmunoassay to the thyroid hormones has now rendered the measurement of $T_{3}$ in serum or urine (Chan, Besser, Landon, and Ekins, 1972) a relatively simple procedure suitable for use as a diagnostic tool in the investigation of patients with thyroid disease. Although the concentration of $T_{3}$ in serum, like that of $T_{4}$, varies with changes in circulating TBG levels, nevertheless it has proved to be a precise and reliable method for the detection of thyroid dysfunction. This applies in particular to the diagnosis of hyperthyroidism. The clinical utility of serum $T_{3}$ determinations is summarized in table III. Present evidence suggests

1 Diagnosis of thyrotoxicosis

2 ? Diagnosis of hypothyroidism

3 Assessment of acute changes in thyroid hormone secretion (a) during antithyroid drug therapy; (b) after thyroidectomy; (c) after hypophysectomy

4 Assessment of $T_{4}$ replacement therapy, especially in elderly patients with ischaemic heart disease and in young children

5 Assessment of thyroid gland autonomy eg, after TRH stimulation 6 Assessment of thyroid gland reserve, eg, after TSH stimulation

Table III Clinical utility of serum $T_{3}$ determination

that the measurement of serum $T_{3}$ is a valuable adjunct to the measurement of serum $\mathrm{T}_{4}$ and may eventually replace the latter as a more direct and precise index of thyroidal status in the diagnosis and management of patients with thyroid disease.

This work was carried out during the tenure by C.J.E. of the Overseas Travelling Fellowship in Medicine and the Allied Sciences of the Royal Australasian College of Physicians and subsequently during the tenure of a Wellcome research fellowship. Financial assistance from the Medical Research Council is gratefully acknowledged. The authors are indebted to Miss N. Wechsler for technical assistance and to Dr J. G. B. Millar and Dr N. F. Lawton for helpful advice and assistance in carrying out this work, and to the physicians of The Middlesex Hospital for allowing us to study their patients.

\section{References}

Braverman, L. E., Ingbar, S. H., and Sterling, K. (1970). Conversion of thyroxine $\left(T_{4}\right)$ to triiodothyronine $\left(T_{3}\right)$ in athyreotic human subjects. J. clin. Invest., 49, 855-864.
Brown, B. L., Ekins, R. P.. Ellis, S. M., and Reith, W. S. (1970). 음 Specific antibodies to triiodothyronine hormone. Nature (Lond.), 226, 359-360.

Brown, B. L., Ekins, R. P., Ellis, S. M., and Williams, E. S. (1971). The radioimmunoassay of triiodothyronine. In Further $\bar{\complement}$ Advances in Thyroid Research (6th International Conference) $\overline{0}$ edited by K. Fellinger and R. Höfer, p. 1107. Academy of $\overline{\bar{c}}$ Medicine, Vienna.

Chan, V., Besser, G. M., Landon, J. J., and Ekins, R. P. (1972). $\stackrel{\mathbb{Q}}{\stackrel{Q}{Q}}$ Urinary tri-iodothyronine excretion as index of thyroid function. Lancet, 2, 253.

Chopra, I. J. (1972). A radioimmunoassay for measurement of $\rightarrow$ thyroxine in unextracted serum. J. clin. Endocr., 34, 938-947.

Chopra, I. J., Ho, R. S., and Lam, R. (1972). An improved radio- immunoassay of triiodothyronine in serum: its application to $\vec{\omega}$ clinical and physiological studies. J. Lab. clin. Med., 80, 729.

Chopra, I. J., Solomon, D. H., and Beall, G. N. (1971). Radioimmunoassay for measurement of triiodothyronine in human? serum. J. clin. Invest., 50, 2033-2041.

Eastman, C. J., Corcoran, J. M., Jequier, A., Ekins, R. P., and $\infty$ Williams, E. S. (1973). Triiodothyronine concentration in $\omega$ cord and maternal sera at term. Clin. Sci., 45, 251-255. iv

Ekins, R. P., Williams, E. S., and Ellis, S. M. (1969). The sensitive $\mathcal{N}$ and precise measurement of serum thyroxine by saturation analysis (competitive protein binding assay). Clin. Biochem., 윽 $2,253$.

Fisher, D. A., and Dussault, J. H. (1971). Contribution of methodological artefacts to the measurement of $T_{3}$ concentration in serum. J. clin. Endocr., 32, 675-679.

Gharib, H., Ryan, R. J., Mayberry, W. E., and Hockert, T. (1971). $\frac{\rho}{\supset}$ Radioimmuno-assay for triiodothyronine $\mathrm{LT}_{3}$. I. Affinity and specificity of the antibody for $\mathrm{T}_{3}$. J. clin. Endocr., 33, 509.

Gross, J., and Pitt-Rivers, R. (1952). The identification of 3,5,3'-Ltriiodothyronine in human plasma. Lancet, 1, 439-441.

Hesch, R. D., Hüfner, M., and Von Zu Mühlen Mühlen, A. (1972). The radioimmunoassay of triiodothyronine. (Abstr.). In Pro- O ceedings of the IVth International Congress of Endocrinology, p. 613 .

Hollander, C. S. (1968). On the nature of circulating thyroid hormone: ֻ clinical studies of triiodothyronine and thyroxine in serum using gas chromatographic methods. Trans. Ass. Amer. Phys., 81, 76-79.

Hollander, C. S., and Shenkman, L. (1972). T ${ }_{3}$ toxicosis. Brit. J. Hosp. $\overrightarrow{\bar{O}}$ Med., 8, 393-395.

Larsen, P. R. (1971a). Technical aspects of the estimation of triiodothyronine in human serum. Evidence of conversion of thyroxine to triiodothyronine during assay. Metabolism, 20, 609-624.

Larsen, P. R. (1971b). Salicylate-induced increases in free triiodothyro $=$ nine in human serum: evidence of inhibition of triicdothyronine? binding to thyroxine-binding globulin and thyroxine binding. pre-albumin. J. clin., Invest., 51, 1125-1234.

Larsen, P. R. (1972). Direct immunoassay of triiodothyronine in human serum. J. clin. Invest., 51, 1939-1949.

Lieblich, J., and Utiger, R. D. (1972). Triiodothyronine radio-윽 immunoassay. J. clin. Invest., 51, 157-166.

Mitsuma, T., Colucci, J., Shenkman, L., and Hollander, C. S. (1972). Rapid simultaneous radioimmunoassay for triiodothyronine and thyroxine in unextracted serum. Biochem. Biophys. D Res. Commun., 46, 2107-2113.

Mitsuma, T., Gershengorn, M., Colucci, J., and Hollander, C. S. 三 (1971). Radioimmunoassay of triiodothyronine in unextracted $\mathrm{N}$ human serum. J. clin. Endocr., 33, 364-367.

Nauman, J. A., Nauman, A., and Werner, S. C. (1967). Total andN free triiodothyronine in human serum. J. clin. Invest., 46, 1346-O 1355.

Nicoloff, J. T., Low, J. C., Dussault, J. H., and Fisher, D. A. (1972) Simultaneous measurement of thyroxine and triiodothyronine? peripheral turnover kinetics in man. J. clin. Invest., 51, 47360

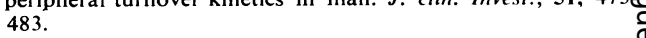

Sterling, K., Bellabarba, D., Newman, E. S., and Brenner, M. A (1969). Determination of triiodothyronine concentration in human serum. J. clin. Invest., 48, $1150-1158$.

Sterling, K., Refetoff, S., and Selenkow, H. (1970). $T_{3}$ thyrotoxicosis $\overline{0}$ thyrotoxicosis due to elevated serum triiodothyronine levels $\vec{D}$ J. Amer. med. Ass., 213, 571-575.

Wahner, H. W., and Gorman, C. A. (1971). Interpretation of serumD triiodothyronine levels measured by the Sterling technique. New Engl. J. Med., 284, 225-230. 